\section{Prikaz knjige: ANATOMIJA}

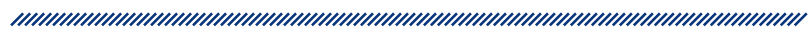

1 Bruno Splavski

1 Klinika za neurokirurgiju, KBC Sestre milosrdnice

Datum primitka: 10.11.2017.

Datum prihvaćanja: 01.12.2017.

DOI: $10.24141 / 1 / 3 / 2 / 15$

\section{Book Review: ANATOMIJA (ANATOMY)}

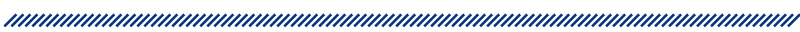

\author{
1 Bruno Splavski \\ 1 Clinical Department of Neurosurgery, Sestre milosrdnice \\ University Hospital Center, Zagreb, Croatia
}

Article received: 10.11 .2017 .

Article accepted: 01.12.2017.

DOI: $10.24141 / 1 / 3 / 2 / 15$

Anatomija, whose authors are Krešimir Rotim and associates, is a new textbook published by the University of Applied Health Sciences. The textbook is intended for students of professional and university studies of biomedicine and health care. It is the official textbook of the University of Applied Health Sciences, University of Applied Sciences Velika Gorica and Josip Juraj Strossmayer University of Osijek.

It has 204 pages, and consists of 12 chapters which describe the anatomy of the human body. The content of the chapters has been adjusted to students of professional studies (physiotherapy, nursing, radiolog- 
sanitarnog inženjerstva te medicinske laboratorijske dijagnostike). Poglavlja su u udžbeniku: Uvod u anatomiju, Koštani sustav, Zglobni sustav, Mišićni sustav, Probavni sustav, Dišni sustav, Mokraćni sustav, Spolni sustav, Endokrini sustav, Kardiovaskularni sustav, Živčani sustav te Osjetila. Udžbenik je pisan hrvatskim jezikom uz anatomsko nazivlje na hrvatskom i latinskom jeziku prema najnovijem nazivlju Terminologia Anatomica.

Jedna je od posebnih vrijednosti ovog udžbenika činjenica kako su njegovi autori redom kliničari koji su mu tako osigurali znanstveni pristup na način kliničke anatomije. Korekturu i recenziju udžbenika učinili su znanstvenici temeljnih medicinskih znanosti iz područja anatomije.

Suradnici koji su sudjelovali u pisanju udžbenika su: Dejan Blažević, Boris Božić, Tomislav Čengić, Stipe Ćorluka, Domagoj Gajski, Ante Rotim, Tomislav Sajko, Nikolina Sesar, Ante Subašić i Ivan Škoro. Autor je i urednik Krešimir Rotim.

U udžbeniku se nalaze 142 anatomske ilustracije koje prikazuju pojedine dijelove ljudskog tijela, a ilustratori su Matej Pašalić i Alma Jović Šimunec, koji su prikaze izradili ručno i digitalno. S obzirom na to da su sve ilustracije u boji, za ovaj se udžbenik može reći da je, uz ostalo, kvalitetan anatomski atlas, čime prednjači među brojnim drugim anatomskim udžbenicima koji se uglavnom sastoje od teksta i tabličnih prikaza. Ilustracije su uredili Dejan Blažević, Tomislav Čengić, Stipe Ćorluka i Domagoj Gajski na način da se na njima nalaze posebne oznake koje studenta upućuju na najvažnije prikazane anatomske tvorbe.

Korekturu udžbenika učinila je Dragica Bobinac, a lektorirala ga je Dunja Aleraj Lončarić. Recenzenti su udžbenika Savo Jovanović, Daniela Malnar, Ljerka Ostojić i Mario Zovak.

Udžbenik se od akademske godine 2017./2018. upotrebljava kao službena nastavna literatura Katedre za anatomiju i fiziologiju Zdravstvenog veleučilišta u Zagrebu. ical technology, occupational therapy, sanitary engineering and laboratory medical diagnostics). The chapters are the following: Introduction to Anatomy, Skeletal System, Joint System, Muscular System, Digestive System, Respiratory System, Urinary System, Reproductive System, Endocrine System, Cardiovascular System, Nervous System and Senses. The textbook was written in the Croatian language, while anatomical terminology was written in both Croatian and Latin, according to the latest terminology "Terminologia Anatomica".

One of the special features of this textbook is the fact that its authors are clinicians, thus ensuring a scientific approach relevant for clinical anatomy. Proofreading and review of the textbook were carried out by scientists of basic medical sciences from the field of anatomy.

The associates who participated in the preparation of the textbook are: Dejan Blažević, Boris Božić, Tomislav Čengić, Stipe Ćorluka, Domagoj Gajski, Ante Rotim, Tomislav Sajko, Nikolina Sesar, Ante Subašić and Ivan Škoro. Krešimir Rotim is the author and editor.

The textbook contains 142 anatomical illustrations depicting individual parts of the human body. The illustrators are Matej Pašalić and Alma Jović Šimunec, who created the illustrations both manually and digitally. Since it contains colour illustrations, this textbook can be used as a quality anatomical atlas, among other things, which puts it at the forefront of anatomy textbooks which mostly consist of text and tables. The illustrations were edited by Dejan Blažević, Tomislav Čengić, Stipe Corluka and Domagoj Gajski so they now contain designations which direct the student to the most important parts of anatomy.

Proofreading was performed by Dragica Bobinac, and copy editing by Dunja Aleraj Lončarić. The textbook reviewers were Savo Jovanović, Daniela Malnar, Ljerka Ostojić and Mario Zovak.

Since the academic year $2017 / 2018$, the textbook has been used as part of the official teaching literature of the Department of Anatomy and Physiology of the University of Applied Health Sciences in Zagreb. 